\title{
Red and processed meat consumption and purchasing behaviours and attitudes: impacts for human health, animal welfare and environmental sustainability
}

\author{
Angie Clonan ${ }^{1}$, Paul Wilson ${ }^{2, *}$, Judy A Swift ${ }^{3}$, Didier G Leibovici ${ }^{4}$ and \\ Michelle Holdsworth ${ }^{1}$ \\ ${ }^{1}$ School of Health and Related Research, University of Sheffield, Sheffield, UK: ${ }^{2}$ Division of Agricultural and \\ Environmental Sciences, School of Biosciences, University of Nottingham, Loughborough LE 12 5RD, UK: ${ }^{3}$ Division of \\ Nutritional Sciences, School of Biosciences, University of Nottingham, Loughborough, UK: ${ }^{4}$ Centre for Geospatial \\ Science, University of Nottingham, Nottingham, UK
}

Submitted 10 March 2014: Final revision received 16 January 2015: Accepted 22 January 2015: First published online 13 March 2015

\begin{abstract}
Objective: Higher intakes of red and processed meat are associated with poorer health outcomes and negative environmental impacts. Drawing upon a population survey the present paper investigates meat consumption behaviours, exploring perceived impacts for human health, animal welfare and the environment.

Design: Structured self-completion postal survey relating to red and processed meat, capturing data on attitudes, sustainable meat purchasing behaviour, red and processed meat intake, plus sociodemographic characteristics of respondents.

Setting: Urban and rural districts of Nottinghamshire, East Midlands, UK, drawn from the electoral register.

Subjects: UK adults ( $n$ 842) aged 18-91 years, 497 females and 345 males, representing a $35.6 \%$ response rate from 2500 randomly selected residents.

Results: Women were significantly more likely $(P<0 \cdot 01)$ to consume $\leq 1$ portion of meat/d compared with men. Females and older respondents ( $>60$ years) were more likely to hold positive attitudes towards animal welfare $(P<0 \cdot 01)$. Less than a fifth $(18.4 \%)$ of the sample agreed that the impact of climate change could be reduced by consuming less meat, dairy products and eggs. Positive attitudes towards animal welfare were associated with consuming less meat and a greater frequency of 'higher welfare' meat purchases.

Conclusions: Human health and animal welfare are more common motivations to avoid red and processed meat than environmental sustainability. Policy makers, nutritionists and health professionals need to increase the public's awareness of the environmental impact of eating red and processed meat. A first step could be to ensure that dietary guidelines integrate the nutritional, animal welfare and environmental components of sustainable diets.
\end{abstract}

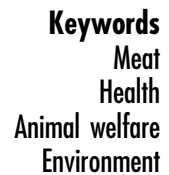

The 20th century witnessed many high-income countries adopting meat as the basis around which meals are prepared $^{(1)}$. These cultural norms have been sustained and reinforced by the increased production efficiency of the animal-food supply chain; meat has become both more widely available and financially accessible. In more recent years this has also had the effect in low-income countries of increasing intakes of foods of animal origin, in particular meat, contributing to rising levels of obesity in these countries $^{(1)}$. The complexity of the issues surrounding meat consumption in a modern era is extensive; consumers should arguably consider personal and family health, their diet-related environmental footprint, animal welfare and fiscal issues ${ }^{(2-5)}$, which are influenced by a range of factors including sociodemographic and gender aspects. Collectively these factors influence attitudes towards food consumption, which are both important in predicting consumer behaviour and potentially modifiable to enhance health or environmental patterns of consumption in a population ${ }^{(6)}$. Hence, understanding the relationship between attitudes towards meat consumption and effective consumer communication strategies to jointly enhance population health and sustainability of food consumption is an important area of research enquiry.

There is a long-standing assumption that meat and dairy products are good for human health ${ }^{(7)}$ and UK dietary 
guidelines currently state: 'Meat is a good source of protein in your diet, as well as vitamins and minerals ${ }^{(8)}$. Protein is an essential nutrient providing amino acids required for normal human growth and development; current UK recommendations for protein consumption stipulate that an average woman and man require approximately $45 \mathrm{~g}$ and $55 \mathrm{~g}$ protein $/ \mathrm{d}$, respectively ${ }^{(9)}$. Protein from red meat sources tends to provide a broader range of amino acids, which are easier for the body to digest than protein from plant-based sources; but also red meat sources tend to be micronutrient-rich foods, in particular $\mathrm{Fe}$, which plays a role in a number of essential functions in the body ${ }^{(10,11)}$. It is unlikely that a large proportion of the UK population is protein deficient, as average daily intakes are about $66 \mathrm{~g}$ (women) and $88 \mathrm{~g}$ (men), almost double requirements ${ }^{(12)}$. In the USA protein intakes are also substantially above recommendations at $70 \mathrm{~g} / \mathrm{d}(102 \mathrm{~g} / \mathrm{d})$ for women (men) ${ }^{(13)}$, while across a range of European countries, Halkjær et al. ${ }^{(14)}$ found overall average protein consumption ranging from 60 to $94 \mathrm{~g} / \mathrm{d}$ ( 72 to $144 \mathrm{~g} / \mathrm{d}$ ) for women (men), highlighting the extent of overconsumption of protein across highincome countries. However, recent evidence points to a clear link between higher meat consumption and risk of certain cancers, as well as $\mathrm{CVD}^{(15,16)}$. The World Cancer Research Fund advocates reducing red meat consumption to no more than $70 \mathrm{~g} / \mathrm{d}^{(16)}$ and the UK Department of Health has incorporated this recommendation into dietary advice for the public: 'If you currently eat more than $90 \mathrm{~g}$ (cooked weight) of red and processed meat a day, the Department of Health advises that you cut down to $70 \mathrm{~g}^{(8)}$. A recent study demonstrates that a sustained reduction in red and processed meat consumption in the UK population would reduce the incidence of $\mathrm{CHD}$, diabetes mellitus and colorectal cancer by $3-12 \%{ }^{(17)}$. Hence, while playing an important dietary role, there is also robust evidence that excess meat consumption is linked to major health problems. At the individual or micro level, there is a strong health argument for reducing meat consumption. Yet meat consumption plays an important role in meal formation ${ }^{(18)}$ and self-identity (including non-meat eating) ${ }^{(19)}$, further complicating the (micro-level) choices consumers face. The consumption of meat is also confounded when considering macro or environmental perspectives. Levels of meat consumption currently observed in the UK are unsustainable because of their contribution to greenhouse gas emissions; meat has a poor input-output resource use when compared with plant-based foods ${ }^{(20,21)}$. Livestock production represents a poor use of arable land in terms of producing human consumable protein per hectare. Current estimates suggest that $66-75 \%$ of European arable land is used to produce animal feed, with $75 \%$ of protein-rich feed derived from South American agricultural production ${ }^{(22)}$, leading to calls for reduced livestock production to lower global greenhouse gas emissions ${ }^{(21,23,24)}$. However, differences in both the type of meat (e.g. beef, pork) and the production method (e.g. intensive, grass-based) also influence the environmental impacts of meat consumption, further complicating consumer choice. While beef and lamb emit more greenhouse gas per kilogram of meat product than pork and chicken ${ }^{(25)}$, grass-fed animals require fewer inputs (e.g. concentrated animal feed, bedding, housing and energy), contribute to carbon sequestration and, with grassfed beef, provide a more favourable nutritional profile ${ }^{(26)}$. The complexity of meat-based food choice, conceptualised by both macro and micro perspectives, has been previously examined $^{(21)}$. At the macro level, recent literature cites the need to produce and consume within planetary bound$\operatorname{aries}^{(27)}$ : the utilisation of resources and the production of negative environmental outputs which are within global environmentally sustainable limits. Moreover, others have noted that biodiversity loss, nitrogen cycle disruption and climate change represent planetary boundaries that have been already transgressed, with land-use change, freshwater use and non-renewable fertiliser demand approaching their respective planetary boundaries ${ }^{(28)}$.

Higher-quality animal welfare production systems have been associated with perceived higher product quality $^{(29,30)}$ for which some consumers are willing to pay a higher product price ${ }^{(31)}$, albeit that free range and organic meat constitutes a small proportion of the total market even in high-income countries ${ }^{(32)}$. However, the environmental-resource use impacts of meat production are further complicated by the trade-off between animal welfare and feed-resource use efficiency ${ }^{(22)}$. Free-range, or less densely populated animal production rearing systems, can also lead to a higher feed requirement to (meat) output ratio, whereby animals expend greater energy in keeping warm and foraging for food, hence reducing feed conversion efficiency ${ }^{(22)}$, and are therefore environmentally more damaging than intensively reared systems. While these competing demands are arguably counterintuitive to individuals considering meat consumption, they serve at best to highlight the complexity of issues with respect to 'sustainable' meat choice and at worst a lack of understanding of the impact of individual food choice on the environment. Indeed, the disconnection between food production and consumption in high-income countries ${ }^{(33)}$ has arguably led consumers to implicitly take a lower degree of ownership over the source of their food. Others have identified that consumers associate animal welfare with animal health and living environment (e.g. free range) and do not consider welfare in more detailed contexts ${ }^{(29)}$; for example, as highlighted by the environmental impacts of higher-quality animal welfare systems.

Consumers with meat-eating environmental concerns may choose to reduce meat consumption as part of a coherent individual action that aligns with their environmental beliefs. However, while such approaches offer potential for reducing meat consumption among consumers who care for nature, proposing meat-free meals may be counterproductive as consumers with lower environment concerns may react to these messages in 
counter-opposing ways ${ }^{(34)}$. Simplistic analyses of 'meateating' $v$. 'non meat-eating' also fail to acknowledge the important aspects of portion size, frequency of meat-based meals and the need for transition pathways as meat reduction strategies in the $\operatorname{diet}^{(35)}$. In the case of the Netherlands, smaller meat portions are also correlated with eating meat on fewer occasions and younger consumers place a lower importance on meat as the prominent meal component $^{(35)}$.

Aspects of gender difference with respect to meat consumption have also received considerable attention ${ }^{(36)}$, with particular studies analysing gender-related attitudes towards animal welfare foods ${ }^{(37,38)}$, organic and environmentally friendly foods ${ }^{(39)}$ and frequency of meatbased meal occasions ${ }^{(40)}$; studies have confirmed a priori hypotheses that female meat consumption and female-led family meal construction both lead to lower meat consumption patterns than observed for males. Similarly, other research has examined the role of socio-economic drivers towards meat consumption ${ }^{(5,29)}$. Other findings have explored these drivers, for example noting that consumer desire for greater product information, and greater emphasis on product quality, are associated with higher socio-economic groups ${ }^{(41)}$.

Hence, it is clear from the literature that consumers are faced with a barrage of options and conflicting messages with respect to meat consumption. The purpose of the present study was to investigate consumer's self-reported red and processed meat consumption (from intake and purchasing data) against/towards animal welfare, human health and environmental sustainability.

\section{Materials and methods}

The complexity of micro and macro factors involved in meat consumption raise empirical and methodological issues. Previous empirical analysis has tended to draw upon the use of population survey or focus group approaches. Within population surveys, the use of attitudinal, preference, action or intention statements provides an appropriate data capture technique, as evidenced by studies examining animal husbandry ${ }^{(29)}$, plant-based protein diets ${ }^{(21)}$, meat portion size ${ }^{(42)}$, animal welfare ${ }^{(30,42)}$ and impacts of meat consumption on the environment ${ }^{(34)}$. The current paper draws upon this accepted approach within the context of UK-based meat consumption considerations, exploring consumption behaviour with reference to impacts for human health, animal welfare and the environment.

\section{Design and sample}

Self-administered questionnaires were posted to 2500 Nottinghamshire residents in the East Midlands area of England, UK, accompanied by an invitation letter, an information sheet and a freepost return envelope. The demographics of the East Midlands area are in line with the UK overall on a number of indicators (life expectancy, age profile, employment rate, gross weekly earnings) ${ }^{(43)}$ and provides a geographical area that captures both urban and rural areas which has been previously identified as an important driver of meat and fish consumption $^{(44)}$. Participants were randomly selected from five electoral registers encompassing both urban (Nottingham City, Broxtowe, Gedling and Erewash) and rural (Rushcliffe) areas and covering approximately 350000 electors. A random number generation technique was undertaken to select the database from which to sample. Estimates from previous studies ${ }^{(45)}$ identified that females present a higher response rate than males and to account for the potential issues of gender bias in response, a minimal sample size of 996 returns was calculated. A recent population study in the region achieved a response rate of $42 \cdot 3 \%^{(46)}$, from which an initial minimum sample size of 2371 questionnaires to be distributed was calculated; for pragmatic reasons this sample size was increased to 2500. National statistics indicate that in 2008, red and processed meat consumption in the East Midlands was slightly below the mean consumption for England as a whole $(83.5 \mathrm{~g} /$ person per d compared with $88 \mathrm{~g} /$ person per $\mathrm{d}$, respectively ${ }^{(47)}$. Although this is in line with a number of other English regions, it contrasts with regions of high red and processed meat consumption (North East, South East and South West ${ }^{(47)}$. All non-responders were followed up with reminders after two weeks. All responses were anonymous and no incentives were offered. Data were collected in January 2009.

\section{Measures used}

Attitudinal scales development

A pool of attitudinal items was created from thematic categories that were derived from qualitative interviews conducted by the authors with eleven Nottinghamshire adults $^{(48)}$. The interview schedule used in the qualitative interviews was structured around the consumer guidance for sustainable food provided by Sustain ${ }^{(49)}$ as it provided the best possible working definition for consumers available in the UK at that time. Items were designed using the guiding principles outlined by Oppenheim ${ }^{(50)}$; for example, some items were worded positively and some negatively to avoid acquiescence response bias.

The questionnaire was piloted with a sample of fortytwo females and thirty-eight males, recruited using opportunistic sampling. Frequency analysis was conducted on the pilot data and several statements were either removed or replaced due to their poor discriminative properties. The resultant scale was also assessed for readability using the Flesch-Kincaid Reading Grade Level and achieved a score of $3 \cdot 8$, indicating it was suitable reading material for 10-11-year-olds and therefore acceptable for use with the general UK population ${ }^{(51)}$. A five-point Likert scale was used for attitudinal statements 
Table 1 Consumer attitudes to buying and consuming meat and animal welfare adults $(n$ 842) aged 18-91 years from urban and rural districts of Nottinghamshire, East Midlands, UK, January 2009

\begin{tabular}{|c|c|c|c|c|c|c|c|}
\hline \multirow[b]{2}{*}{ Attitudes to meat } & \multicolumn{2}{|c|}{$\begin{array}{l}\text { Strongly agree/ } \\
\text { agree }\end{array}$} & \multicolumn{2}{|c|}{$\begin{array}{l}\text { Neither agree/ } \\
\text { disagree }\end{array}$} & \multicolumn{2}{|c|}{$\begin{array}{l}\text { Disagree/strongly } \\
\text { disagree }\end{array}$} & \multirow[b]{2}{*}{ Cronbach's a } \\
\hline & $n$ & $\%$ & $n$ & $\%$ & $n$ & $\%$ & \\
\hline l'm very fussy about where my meat comes from & 443 & $56 \cdot 2$ & 219 & $27 \cdot 8$ & 126 & $16 \cdot 0$ & 0.75 \\
\hline I always try to buy meat which has been reared in the UK & 509 & $64 \cdot 0$ & 185 & $23 \cdot 3$ & 101 & $12 \cdot 7$ & \\
\hline $\begin{array}{l}\text { I think it is important to buy meat that has been produced } \\
\text { with good standards of animal welfare }\end{array}$ & 711 & 88.5 & 79 & 9.8 & 13 & 1.6 & \\
\hline Animal welfare standards in the UK are very high & 439 & 54.6 & 296 & $36 \cdot 8$ & 69 & 8.6 & \\
\hline $\begin{array}{l}\text { I don't like the ideas of lots of animals being reared } \\
\text { indoors }\end{array}$ & 654 & $81 \cdot 1$ & 116 & $14 \cdot 4$ & 36 & 4.5 & \\
\hline $\begin{array}{l}\text { I choose food which has been produced in a way that } \\
\text { minimises cruelty to animals }\end{array}$ & 567 & $72 \cdot 1$ & 188 & $23 \cdot 9$ & 31 & 3.9 & \\
\hline I buy free range meat where possible & 449 & $57 \cdot 9$ & 224 & $28 \cdot 9$ & 103 & $13 \cdot 3$ & \\
\hline I don't really think much about the animal when I buy meat & 178 & 22.9 & 202 & $26 \cdot 0$ & 398 & $51 \cdot 2$ & \\
\hline $\begin{array}{l}\text { To help reduce the impact of climate change, it is better to } \\
\text { eat less animal foods (meat, dairy products and eggs) }\end{array}$ & 146 & $18 \cdot 4$ & 364 & $45 \cdot 8$ & 28 & $35 \cdot 8$ & \\
\hline
\end{tabular}

with the scale ranging from 'strongly agree' through to 'strongly disagree'; participants were also able to state that the item was 'not applicable' to account for non-meat eaters and to reduce false reporting. To simplify analysis, responses to the attitudinal variables were collapsed into 'agree' (combined responses for 'strongly agree' and 'agree'), 'neither agree nor disagree' and 'disagree' (combined responses for 'strongly disagree' and 'disagree'). Nine items related to meat purchase, animal welfare and meat consumption were used in the current study (Table 1) which, when taken together, produced a Cronbach's $\alpha$ coefficient of 0.75 indicating that the construct was internally consistent and therefore reliable ${ }^{(52)}$. In addition, the nine items produced a good spread of responses (Table 1), establishing their face validity ${ }^{(50)}$.

\section{Red and processed meat purchasing behaviour}

Participants were asked to indicate the frequency that they purchased a range of categories of sustainable food on a regular basis to capture typical behaviour rather than requesting data for a particular time frame (e.g. a week). For red meat, participants were asked to choose whether they purchased 'local', 'organic', 'free range' or 'RSPCA (Royal Society for the Prevention of Cruelty to Animals) Freedom Food' labelled red and processed meat using a four-point frequency scale of 'always', 'often', 'sometimes' or 'never'. Data were re-coded to create a score for 'sustainable' meat purchases. The 'always' or 'often' categories were re-coded together, and the 'sometimes' and 'never' categories remained separate. This produced a 'sustainable meat purchasing' variable, from which two groups of respondents were identified: those reporting a high frequency of sustainable meat purchasing and those reporting low or no sustainable meat purchasing.

\section{Red and processed meat dietary intake}

A semi-quantitative FFQ to assess dietary intake was developed based on the five food groups defined in the
UK's food-based dietary guidelines, the eatwell plate ${ }^{(53)}$. Participants were asked to choose how frequently they ate a portion of red meat and processed meat on a usual basis, using a scale of 'never', 'less than once per week', 'once per week', 'two to three times per week', 'four to six times per week', 'once per day' and 'twice a day or more'. Standard food portion sizes were included based on national food portion sizes, which for both red meat and processed meat were $75-100 \mathrm{~g}$, together with an image depicting one portion size. Using this information, daily intakes were calculated.

\section{Sociodemographic characteristics}

Socio-economic and demographic data were collected at both individual (gender, age, educational level, profession) and household levels (urban/rural, household income). Age groups were created by dividing participants into four categories: 18-30 years, 31-45 years, 46-60 years and 61-91 years. Using multiple correspondence analyses, a socio-economic score was created that ranked participants using four demographic variables: educational level, occupation, household income and individual food spend (calculated using household food spend/number of people in household). The socio-economic score produced a Cronbach's $\alpha$ coefficient of 0.7 indicating internal consistency ${ }^{(51)}$. Participants were then ranked and divided into three groups: higher, medium and lower socioeconomic status, each tertile representing one-third of the sample.

\section{Statistical analysis}

Data were entered into the SPSS statistical software package version $16 \cdot 0$ using EpiData software version $3 \cdot 1$. An intra-rater reliability check was conducted on a random $10 \%$ sample of questionnaires which revealed an error rate of $<1 \%{ }^{(54)}$. Categorical data were analysed using $\chi^{2}$ tests, followed by adjusted $\chi^{2}$ tests to ensure that 
observed differences were not confounded by gender, age group and socio-economic group. Significance was taken as $P<0.05$.

\section{Ethical considerations}

The study was conducted according to the guidelines laid down in the Declaration of Helsinki and all procedures involving human subjects were approved by the University of Nottingham Medical School Ethics Committee. Informed consent of participants was obtained by voluntary completion and return of the questionnaire.

\section{Results}

\section{Response rate}

Of the 2500 individuals invited to participate in the study, 842 usable responses were received. Following adjustment for people who had moved/died, a response rate of $35.6 \%$ was achieved which is lower than recent similar studies $(42.3 \%)^{(46)}$ despite similar protocols being adopted that included reminder letters and questionnaires to

Table 2 Sociodemographic characteristics of participants: adults ( $n$ 842) aged 18-91 years from urban and rural districts of Nottinghamshire, East Midlands, UK, January 2009

\begin{tabular}{lll}
\hline & $n$ & $\%$ \\
\hline Gender & & \\
Male & 333 & $40 \cdot 1$ \\
Female & 497 & $59 \cdot 9$ \\
Age group (years) & & \\
$18-30$ & 101 & $12 \cdot 2$ \\
$31-45$ & 185 & $22 \cdot 4$ \\
$46-60$ & 262 & $31 \cdot 8$ \\
$61-91$ & 277 & 33.6 \\
Socio-economic group & & \\
Higher & 280 & 33.3 \\
Medium & 280 & 33.3 \\
Lower & 282 & 33.5 \\
\hline
\end{tabular}

non-respondents. One explanation for the lower response rate may be the length of the questionnaire employed in the current study. Within the final sample participants ranged from 18 to 91 years of age, the majority of whom were in the two oldest age groups $(31.8 \%$ aged $46-60$ years; $33.6 \%$ aged $\geq 61$ years; Table 2 ). Over half of the sample was female ( $n$ 497, 59.9\%).

\section{Red and processed meat intake}

Over one-quarter of respondents $(26 \cdot 2 \%)$ consumed red meat daily or almost every day, whereas processed meat was consumed less regularly (3\% consumed it once daily or more), with over three-quarters (78.6\%) of respondents reporting eating it once weekly or less.

Women were more likely $\left(\chi^{2}=7.44 ; P<0 \cdot 01\right)$ to consume red meat less often compared with men (Table 3 ). No significant relationship was observed between meat consumption and age or socio-economic group.

\section{Attitudes towards meat consumption}

The oldest age group of respondents ( $\geq 61$ years) was significantly more likely than younger people to agree that they are very fussy about where their meat comes from $\left(\chi^{2}=39.26 ; P<0.001\right)$, that they always try to buy meat reared in the UK $\left(\chi^{2}=34.22 ; \quad P<0.001\right)$, that animal welfare standards in the UK are very high $\left(\chi^{2}=58 \cdot 15\right.$; $P<0.001)$ and that they choose food which has been produced in a way that minimises cruelty to animals $\left(\chi^{2}=16.96 ; \quad P<0.05\right.$; Table 4). Arguably the higher response rate from older residents has implications for the representativeness of the findings, which represents a potential caveat to our findings.

Attitudinal differences to meat consumption (Table 4) were also observed for gender, as women were more likely than men to agree that they are very fussy about where their meat comes from $\left(\chi^{2}=20.70 ; P<0.001\right)$ and always try to buy meat which has been reared in the UK

Table 3 Relationship between red and processed meat consumption and sociodemographic profile among adults $(n$ 842) aged $18-91$ years from urban and rural districts of Nottinghamshire, East Midlands, UK, January 2009

\begin{tabular}{|c|c|c|c|c|c|c|}
\hline & \multicolumn{2}{|c|}{ Low consumption ( $\leq 1$ portion of meat/d) } & \multicolumn{2}{|c|}{ High consumption ( $>1$ portion of meat/d) } & \multirow[b]{2}{*}{$x^{2}$} & \multirow[b]{2}{*}{ Adjusted $\dagger$} \\
\hline & $n$ & $\%$ & $n$ & $\%$ & & \\
\hline \multicolumn{7}{|l|}{ Gender } \\
\hline Male & 190 & $57 \cdot 4$ & 141 & $42 \cdot 5$ & $7 \cdot 59^{*}$ & $7 \cdot 44^{\star \star}$ \\
\hline Female & 327 & $66 \cdot 8$ & 162 & $33 \cdot 1$ & & \\
\hline \multicolumn{7}{|c|}{ Age group (years) } \\
\hline $18-30$ & 60 & $59 \cdot 4$ & 41 & $40 \cdot 5$ & $2 \cdot 22$ & 3.09 \\
\hline $31-45$ & 117 & $63 \cdot 2$ & 68 & $36 \cdot 7$ & & \\
\hline $46-60$ & 174 & $66 \cdot 6$ & 87 & $33 \cdot 3$ & & \\
\hline 61-91 & 166 & $61 \cdot 7$ & 103 & $38 \cdot 2$ & & \\
\hline \multicolumn{7}{|c|}{ Socio-economic group } \\
\hline Lower & 185 & 66.5 & 93 & 33.4 & 2.97 & 2.47 \\
\hline Middle & 176 & 63.5 & 101 & $36 \cdot 4$ & & \\
\hline Higher & 163 & $59 \cdot 4$ & 111 & 40.5 & & \\
\hline
\end{tabular}

${ }^{\star} P<0.05,{ }^{\star \star} P<0.01$.

†Adjusted for gender, age and socio-economic group. 
Table 4 Relationship between attitudes and sociodemographic profile among adults ( $n$ 842) aged 18-91 years from urban and rural districts of Nottinghamshire, East Midlands, UK, January 2009

\begin{tabular}{|c|c|c|c|}
\hline Attitudinal item & $\begin{array}{l}\text { Gender } x^{2} \\
\text { (adjusted }+ \text { ) }\end{array}$ & $\begin{array}{l}\text { Age group } x^{2} \\
\text { (adjusted } t)\end{array}$ & $\begin{array}{l}\text { Socio-economic group } x^{2} \\
\text { (adjusted } \dagger \text { ) }\end{array}$ \\
\hline I'm very fussy about where my meat comes from & $20 \cdot 70^{\star \star \star}$ & $39 \cdot 26^{\star \star \star}$ & $12 \cdot 90^{*}$ \\
\hline I always try to buy meat which has been reared in the UK & $5 \cdot 98^{*}$ & $34 \cdot 22^{\star \star \star}$ & 5.54 \\
\hline $\begin{array}{l}\text { I think it is important to buy meat that has been produced with good standards } \\
\text { of animal welfare }\end{array}$ & $\ddagger$ & $\ddagger$ & $\ddagger$ \\
\hline Animal welfare standards in the UK are very high & 4.56 & $58 \cdot 15^{\star \star \star}$ & $7 \cdot 76$ \\
\hline I don't like the ideas of lots of animals being reared indoors & $10 \cdot 88^{\star \star}$ & $\ddagger$ & 2.51 \\
\hline $\begin{array}{l}\text { I choose food which has been produced in a way that minimises cruelty to } \\
\text { animals }\end{array}$ & $7 \cdot 21^{*}$ & $16 \cdot 96^{*}$ & 3.51 \\
\hline I buy free range meat where possible & 4.86 & 11.35 & 0.55 \\
\hline I don't really think much about the animal when I buy meat & $7 \cdot 25^{\star}$ & 5.63 & 4.36 \\
\hline $\begin{array}{l}\text { To help reduce the impact of climate change, it is better to eat less animal } \\
\text { foods (meat, dairy products and eggs) }\end{array}$ & $3 \cdot 21$ & $7 \cdot 86$ & $2 \cdot 85$ \\
\hline
\end{tabular}

${ }^{*} P<0.05,{ }^{* *} P<0.01,{ }^{* \star *} P<0.001$.

†Adjusted for gender, age and socio-economic group.

†Insufficient cell count to conduct $x^{2}$ testing as $<5$ responses in a cell.

Table 5 Relationship between attitudes to meat and meat consumption and sustainable meat purchases among adults ( $n$ 842) aged 18-91 years from urban and rural districts of Nottinghamshire, East Midlands, UK, January 2009

\begin{tabular}{|c|c|c|}
\hline Attitudinal item & $\begin{array}{l}\text { Meat consumption } \\
\text { (high } v \text {. low) } x^{2}\end{array}$ & $\begin{array}{l}\text { Sustainable meat purchase } \\
\text { frequency (high } v \text {. little/no) } X^{2}\end{array}$ \\
\hline I'm very fussy about where my meat comes from & $6.51^{*}$ & $45 \cdot 96^{\star \star \star}$ \\
\hline I always try to buy meat which has been reared in the UK & $6 \cdot 34$ & $67.59^{\star \star \star}$ \\
\hline $\begin{array}{l}\text { I think it is important to buy meat that has been produced with good } \\
\text { standards of animal welfare }\end{array}$ & $\ddagger$ & $19 \cdot 02^{\star \star \star}$ \\
\hline Animal welfare standards in the UK are very high & $11 \cdot 06^{\star *}$ & $1 \cdot 10$ \\
\hline I don't like the ideas of lots of animals being reared indoors & $14 \cdot 81^{\star \star \star}$ & 2.90 \\
\hline $\begin{array}{l}\text { I choose food which has been produced in a way which minimises cruelty to } \\
\text { animals }\end{array}$ & 4.53 & $38 \cdot 34^{\star \star *}$ \\
\hline I buy free range meat where possible & 0.83 & $45 \cdot 89^{\star * *}$ \\
\hline I don't really think much about the animal when I buy meat & $8 \cdot 39^{* *}$ & $67 \cdot 59^{\star \star *}$ \\
\hline $\begin{array}{l}\text { To help reduce the impact of climate change, it is better to eat less animal } \\
\text { foods (meat, dairy products and eggs) }\end{array}$ & $1 \cdot 29$ & $2 \cdot 30$ \\
\hline
\end{tabular}

${ }^{\star} P<0.05,{ }^{\star *} P<0.01,{ }^{\star * \star} P<0.001$.

†Local, organic, free range and RSPCA (Royal Society for the Prevention of Cruelty to Animals) Freedom Food.

flnsufficient cell count to conduct $X^{2}$ testing as $<5$ responses in a cell.

$\left(\chi^{2}=5.98 ; P<0.05\right)$. Female respondents were also more likely to agree that they do not like the idea of indoor animal rearing $\left(\chi^{2}=10 \cdot 88 ; P<0 \cdot 01\right)$ and to agree that they choose food which has been produced in a way that minimises cruelty to animals $\left(\chi^{2}=7 \cdot 21 ; P<0.05\right)$. Finally, women were more likely to disagree that they did not really think much about the animal when they purchased meat $\left(\chi^{2}=7 \cdot 25 ; P<0.05\right)$.

The only relationship observed between attitudes to meat and socio-economic group was for the statement 'I'm very fussy about where my meat comes from', whereby respondents from the highest socio-economic group were more likely to agree $\left(\chi^{2}=12.90 ; P<0.05\right.$; Table 4$)$.

\section{Relationship between red and processed meat consumption and purchasing behaviour and attitudes}

Low meat eaters, i.e. consuming $\leq 1$ portion of meat/d, were more likely to agree that they were fussy about where their meat came from $\left(\chi^{2}=6.51 ; P<0.05\right)$ and to agree that they did not like the idea of animals being reared indoors $\left(\chi^{2}=14.81 ; P<0.001\right.$; Table 5$)$. Low meat eaters were more likely to disagree that they did not think much about the animal when buying meat than other respondents $\left(\chi^{2}=8.39 ; P<0 \cdot 01\right)$. Low meat eaters were also less likely to believe that 'animal welfare standards in the UK are very high' compared with those consuming $>1$ portion of meat/d $\left(\chi^{2}=11.06 ; P<0 \cdot 01\right)$.

Respondents in the group that purchased sustainable meat (local, organic, free range and RSPCA Freedom Food) more frequently were more likely to have positive attitudes towards sustainable meat consumption (Table 5). This group also tended to disagree with the statement 'I don't really think about the animal when I buy meat' $\left(\chi^{2}=67.59 ; P<0 \cdot 001\right)$.

There were no associations between sustainable meat purchasing and gender or socio-economic group; however, age group almost reached significance $\left(\chi^{2}=7 \cdot 60\right.$; 
$P=0.055)$, with respondents from the two oldest age groups ( $\geq 46$ years old) more likely to report frequently purchasing sustainable meat.

\section{Discussion}

The purpose of the present study was to investigate consumer's self-reported red and processed meat consumption (from intake and purchasing data) against their stated attitudes towards animal welfare, human health and environmental sustainability.

\section{Animal welfare}

Animal welfare appears to be particularly important to respondents, as $88.5 \%$ of respondents believed it was important that the meat they buy has been produced with good animal welfare standards. This sentiment is consistent with other research findings for UK consumers $^{(55,56)}$. Our findings demonstrate that over half of respondents try to buy meat reared in the UK and believe UK standards are very high, buy free range meat where possible and agree that they are fussy about where their meat comes from. These findings accord with previous research that animal welfare is associated with higher product quality perceptions ${ }^{(29,30)}$. Some of the concern identified in the present study may have arisen from the media coverage of animal rearing (e.g. Channel 4's The F Word and Big Food Fight, which explored poultry, pig and lamb production ${ }^{(57,58)}$, aired prior to and during data collection) and correlates with evidence on the impact of media coverage in the $\mathrm{USA}^{(59)}$. The impact of gender on attitudes towards animal welfare in the present study also reinforced findings from previous studies, with female consumers being more conscious of country of origin and welfare production method ${ }^{(37)}$. Other findings have highlighted that UK consumers associate higher animal welfare with good health and additionally view it as an indicator of food safety ${ }^{(60)}$.

\section{Environmental sustainability and meat consumption}

In contrast to the interest in animal welfare shown among the sample, awareness of climate change reduction strategies in terms of consuming animal foods (meat, dairy products and eggs) appears to be low. Under a fifth of the sample agreed that 'To help reduce the impact of climate change, it is better to eat less animal foods', reinforcing findings from Australia reporting public perception of a low environmental impact of meat consumption ${ }^{(61)}$. Similar studies conducted in Switzerland and the Netherlands proposed that low levels of awareness could be linked to denial, due to perceived difficulties in reducing meat consumption $^{(62,63)}$. It found that respondents holding health and environmental concerns reported the lowest meat intakes. However, building upon other evidence ${ }^{(22)}$, it could be argued that while consumers eating low amounts of meat stated greater concern for animal welfare, their consumption choices of higher welfare foods may counterintuitively negate some of the environmental benefit derived from their relatively lower meat consumption with respect to minimising climate change impacts. Previous research identified that consumers perceive animal welfare to relate to animal health and production environment ${ }^{(29)}$. Given the sustainability conflict between welfare and environment ${ }^{(22)}$, further incentivising animal-welfare-conscious consumers towards a lower meat-based diet, or one with reduced meat portion size ${ }^{(35)}$, may be the most effective environmental strategy for this subset of consumers. However, attempting to achieve reductions in meat consumption among consumers unconvinced by climate change considerations may result in unexpected outcomes ${ }^{(34)}$.

\section{Drivers of meat consumption}

Those consuming meat more often in the present study were typically young males from higher socio-economic groups; in contrast, women aged 46-60 years from lower socio-economic groups consumed the lowest quantities of meat. Overall, women reported consuming less meat than men, supporting gender differences in meat consumption previously identified $^{(62,64)}$ and reinforcing the suggested link between 'virulent masculinity' and meat consumption ${ }^{(62)}$. Associations observed between gender and attitudes towards animal welfare and source of meat purchases were also in concordance with previous international findings from the $\mathrm{UK}^{(65)}$ and other high-income countries ${ }^{(66)}$, whereby women were significantly more likely to show concern over the source of their meat, and for animal welfare, than men.

Older adults (61-91 years) in the present sample displayed more concern towards the source of their meat and animal welfare, potentially influenced by memories of a food system in which meat was in short supply prior to, during and after World War II; pre- and post-war consumption data illustrate that UK meat intakes were lower than current levels, at $58.5 \mathrm{~kg} /$ person per annum in the period 1934-1938 and $44.8 \mathrm{~kg} /$ person per annum in $1942^{(67)}$, set against the recent data for average meat consumption of $84.2 \mathrm{~kg}^{(47)}$. Although the war ended in 1945, meat continued to be rationed until 1954 and following the removal of rationing restrictions, meat prices soared $^{(68)}$. Therefore older respondents may hold a greater appreciation of meat as a food source than younger consumers, with these attitudes flowing from their experience of contrasting food availability. Respondents in the highest socio-economic group were more likely to agree that they are very fussy about where their meat comes from and this arguably highlights the issue of cost as a barrier to lower socio-economic groups in making more selective purchases ${ }^{(69)}$. Moreover, level of education may play a role in respondents being conscious of the production source of their meat purchase ${ }^{(70)}$, arguably 
also concurring with previous research linking higher educational levels with increased likelihood of choosing a vegetarian diet $^{(63)}$.

It is unsurprising that those consuming less meat were more likely to think about both the provenance of the meat they ate and also animal welfare when buying meat. However, what is more revealing is that higher meat consumers were more likely to agree that animal welfare standards in the UK are very high, perhaps implying that more frequent meat consumers either assume that meat of UK origin has been reared to high animal welfare standards or simply that they do not think critically about the issue. One suggestion is that there is a certain level of 'cultural invisibility' surrounding the slaughter of animals for food, in order to normalise the process, and this provides the separation required so that meat can be consumed without really considering the welfare of the animal involved $^{(66)}$. This arguably extends to modern society's categorisation as 'animals for food' and 'companion animals', with childhood experiences embedding these distinctions at an early age ${ }^{(71)}$. Transparency at every stage of the meat chain may lead to more mindful consumption of animal-based products, as previous studies have confirmed that Dutch consumers who are sensitive to animal origin and animal welfare are more likely to favour free range or organic meat ${ }^{(32)}$.

\section{Implications for policy and practice}

Low awareness of the link between the consumption of animal products and their environmental impact was observed among respondents in the present study, suggesting the need for public health interventions to raise the profile of this issue. Seeking to raise awareness of animalrearing methods could prove an effective approach, as animal welfare was particularly important to respondents in this and other UK studies; albeit that to ensure both welfare and environmental sustainability outcomes, such approaches need to align with portion size, or frequency of meat-based meal, reduction strategies ${ }^{(35)}$. Examples of success in promoting dietary change include Korea ${ }^{(1)}$, where a campaign focused on increasing the consumption of low-fat high-vegetable meals; this approach could prove successful if adopted in other countries, particularly if pricing mechanisms are supported by policy measures that promote plant-based agriculture to produce fruit, vegetables, beans and pulses for human consumption instead of subsidising animal-source foods (as has been the case historically alongside non-vegetable arable crops). This could incentivise consumers to lower their intakes of meat while having the added advantage of reducing saturated fat intakes and increasing fibre intakes $^{(34)}$.

Taxing red and processed meat could be considered with the recognition that information sources alone do not lead to direct immediate diet change, but can play a role in longer-term social acceptance of consumption behaviour.
However, it is important to consider how fiscal measures on red meat may affect certain groups of the population, for example pregnant women and younger children who may be at risk of developing micronutrient deficiencies and for whom cost may already be a barrier to accessing quality sources of protein ${ }^{(10)}$. Public education campaigns seeking to achieve a reduction in meat consumption may, therefore, wish to target those groups identified as higher meat consumers, in particular the male population. There is a need for dietitians, nutritionists and other health professionals to be adequately informed on this issue and understand how best this message can be communicated to patients, clients and the wider public.

Policy makers need to ensure that dietary guidelines go beyond consideration for current consumers and encompass the nutritional, environmental and resource needs of future generations. In view of the environmental damage caused by livestock farming, the evidence base should consider how best to meet not just protein, but also Fe and Se requirements from other, less environmentally costly dietary sources. Although UK dietary guidelines do advise a reduction in red and processed meat consumption, meat has become deeply entrenched in the UK diet and consideration needs to be given to social and cultural norms that need to undergo a massive shift to obtain the necessary reductions in consumption to facilitate environmental sustainability. The influence of the built and retail environment on meat purchasing decisions needs further research, to explore how retailers can edit choice at a food supply level, to simplify the situation for consumers wishing to purchase meat that is healthy and has been reared to high standards of animal welfare and environmental sustainability.

\section{Limitations}

Caveats to the present study include the regional sample frame within which the research was conducted and the need to define at the outset descriptors of attitudes that respondents could understand; these considerations are often encountered when exploring consumer attitudes in population surveys. Moreover, despite embedding a protocol that included distribution of a reminder letter and questionnaire to non-respondents, a lower than anticipated response rate was achieved together with a lower response rate from younger residents. Another issue may have been the lack of incentive offered. These issues represent potential response bias in our results, albeit that achieving high response rates with unbiased sociodemographic responses is generally recognised as increasingly challenging within population surveys. However, our analyses were adjusted for the sociodemographic factors, which ensured that any observed differences were not confounded by gender, age or socioeconomic group. The study was cross-sectional so we are unable to say whether attitudes influence actual behaviour 
in relation to consumption of red or processed meat or purchasing of sustainable meat. The gap between attitudes and intention and actual behaviour is well established in work involving social cognitive models ${ }^{(72,73)}$. Hence we are only able to conclude on associations and not causation of attitudes on behaviour. However, accepting these caveats, the present study has both reinforced findings from previous research that has investigated attitudes towards meat consumption and placed these within the context of environmental sustainability, raising important considerations for both policy makers and consumers.

\section{Conclusion}

In the present study, low red and processed meat consumption is associated with concerns regarding animal welfare while self-reported purchasing of sustainable meat is associated with positive attitudes to sustainable meat consumption. This suggests that attitudes towards animal welfare and sustainability might therefore be important motivators of behaviour and represent components of future campaigns to reduce meat consumption and promote health. Achieving environmental and nutritional sustainability will require coordinated action from a range of stakeholders; understanding public attitudes towards meat consumption is a necessary condition for successfully adopting a more sustainable food supply.

\section{Acknowledgements}

Acknowledgements: The authors wish to thank two anonymous reviewers and the Associate Editor for their constructive comments on the original submission. Financial support: This work was supported by the University of Nottingham. With the exception of the authors, the University of Nottingham had no role in the design, analysis or writing of this article. Conflict of interest: None. Authorship: A.C. devised the questionnaire, undertook data analysis, reviewed literature and contributed to writing the manuscript. P.W. advised on questionnaire design, reviewed literature and contributed to writing the manuscript. J.A.S. devised the questionnaire, reviewed literature and contributed to writing the manuscript. D.G.L. advised on questionnaire design, undertook data analysis and reviewed the manuscript. M.H. devised the questionnaire, undertook data analysis, reviewed literature and contributed to writing the manuscript. Ethics of buman subject participation: This study was conducted according to the guidelines laid down in the Declaration of Helsinki and all procedures involving human subjects were approved by the University of Nottingham Medical School Ethics Committee. Informed consent of participants was obtained by voluntary completion and return of the questionnaire.

\section{References}

1. Keats S \& Wiggins S (2014) Future Diets: Implications for Agriculture and Food Prices. London: Overseas Development Institute.

2. Schifferstein HN \& Oude Ophuis PA (1998) Health-related determinants of organic food consumption in the Netherlands. Food Qual Prefer 9, 119-133.

3. Hupkens CL, Knibbe RA \& Drop MJ (2000) Social class differences in food consumption: the explanatory value of permissiveness and health and cost considerations. Eur $J$ Public Health 10, 108-113.

4. Foster C, Green K \& Bleda M (2007) Environmental impacts of food production and consumption: final report to the Department for Environment Food and Rural Affairs. http://agris.fao. org/agris-search/search.do?f=2013/GB/GB2013202500025.xml; GB2013202568 (accessed November 2014).

5. Schröder MJ \& McEachern MG (2004) Consumer value conflicts surrounding ethical food purchase decisions: a focus on animal welfare. Int J Consum Stud 28, 168-177.

6. Vermeir I \& Verbeke W (2006) Sustainable food consumption: exploring the consumer 'attitude-behavioral intention' gap. J Agric Environ Ethics 19, 169-194.

7. Fiddes N (1991) Meat: A Natural Symbol. London: Routledge.

8. Department of Health (2014) Meat in your diet. http://www. nhs.uk/Livewell/Goodfood/Pages/meat.aspx\#reddiet/nutrition essentials/meat/ (accessed December 2014).

9. Department for Health (1991) Dietary Reference Values for Food Energy and Nutrients for the United Kingdom. Report on Health and Social Subjects no. 41. London: HMSO.

10. Millward DJ \& Garnett T (2009) Food and the planet: nutritional dilemmas of greenhouse gas emission reductions through reduced intakes of meat and dairy foods. Proc Nutr Soc 69, 103-118.

11. World Health Organization (2007) Protein and Amino Acid Requirements in Human Nutrition. WHO Technical Report Series no. 935. Geneva: WHO/FAO/UNU.

12. Food Standards Agency (2010) National Diet and Nutrition Survey: Headline Results from Year 1 of the Rolling Programme (2008/2009). London: FSA.

13. NCHStats (2014) Adults' daily protein intake much more than recommended. http://nchstats.com/2010/03/03/adults\%E2\% 80\%99-daily-protein-intake-much-more-than-recommended/ (accessed November 2014).

14. Halkjaer J, Olsen A, Bjerregaard LJ et al. (2009) Intake of total, animal and plant proteins, and their food sources in 10 countries in the European Prospective Investigation into Cancer and Nutrition. Eur J Clin Nutr 63, Suppl. 4, S16-S36.

15. Sinha R, Cross AJ, Graubard BI et al. (2009) Meat intake and mortality. Arch Intern Med 169, 562-571.

16. World Cancer Research Fund/American Institute for Cancer Research (2009) Policy and Action for Cancer Prevention: Food, Nutrition and Physical Activity: A Global Perspective. Washington, DC: AICR.

17. Aston LM, Smith JN \& Powles JW (2012) Impact of a reduced red and processed meat dietary pattern on disease risks and greenhouse gas emissions in the UK: a modelling study. BMJ Open 2, e001072.

18. Lupton D (2000) The heart of the meal: food preferences and habits among rural Australian couples. Sociol Health Ill 22, 94-109.

19. Povey R, Wellens B \& Conner M (2001) Attitudes towards following meat, vegetarian and vegan diets: an examination of the role of ambivalence. Appetite 37, 15-26.

20. MacMillan (2007) Meat Consumption: Trends and Environmental Implications. London: Food Ethics Council.

21. de Boer J \& Aiking H (2011) On the merits of plant-based proteins for global food security: marrying macro and micro perspectives. Ecol Econ 70, 1259-1265. 
22. Westhoek H, Rood T, van den Berg et al. (2011) The Protein Puzzle; The Consumption and Production of Meat, Dairy and Fish in the European Union. The Hague: PBL Netherlands Environmental Assessment Agency.

23. Audsley E, Chatterton J, Graves A et al. (2009) Food, Land and Greenhouse Gases: The Effect of Changes in UK Food Consumption on Land Requirements and Greenhouse Gas Emissions. London: The Committee on Climate Change.

24. Friel S, Dangour AD, Garnett T et al. (2009) Public health benefits of strategies to reduce greenhouse-gas emissions: food and agriculture. Lancet 374, 2016-2025.

25. Msangi S \& Mark R (2009) World agriculture in a dynamically-changing environment: IFPRI's long-term outlook for food and agriculture under additional demands and constraints. Paper presented at the FAO Expert Meeting on How to Feed the World in 2050, FAO Headquarters, Rome, 24-26 June 2009.

26. Langlois E, Campbell K, Prieur-Richard AH et al. (2012) Towards a better integration of global health and biodiversity in the new sustainable development goals beyond Rio + 20. EcoHealth 9, 381-385.

27. Pelletier N \& Tyedmers P (2010) Forecasting potential global environmental costs of livestock production 2000-2050. Proc Natl Acad Sci US A 107, 18371-18374.

28. Rockström J, Steffen W, Noone K et al. (2009) A safe operating space for humanity. Nature 461, 472-475.

29. Frewer LJ, Kole A, van der Kroon S et al. (2005) Consumer attitudes towards the development of animal-friendly husbandry systems. I Agric Environ Ethics 18, 345-367.

30. Phan-Huy SA \& Fawaz RB (2003) Swiss market for meat from animal-friendly production - responses of public and private actors in Switzerland. J Agric Environ Ethics 16 , 119-136.

31. Bennett RM, Anderson J \& Blaney RJ (2002) Moral intensity and willingness to pay concerning farm animal welfare issues and the implications for agricultural policy. J Agric Environ Ethics 15, 187-202.

32. Hoogland CT, de Boer J \& Boersema JJ (2005) Transparency of the meat chain in the light of food culture and history. Appetite 45, 15-23.

33. Marsden T \& Smith E (2005) Ecological entrepreneurship: sustainable development in local communities through quality food production and local branding. Geoforum $\mathbf{3 6}$, 440-451.

34. de Boer J, Schösler H \& Boersema JJ (2013) Climate change and meat eating: an inconvenient couple? J Environ Psychol 33, $1-8$.

35. Schösler H, de Boer J \& Boersema JJ (2012) Can we cut out the meat of the dish? Constructing consumer-oriented pathways towards meat substitution. Appetite 58, 39-47.

36. Burton M, Dorsett R \& Young T (2000) An investigation of the increasing prevalence of nonpurchase of meat by British households. Appl Econ 32, 1985-1991.

37. Verbeke WA \& Viaene J (2000) Ethical challenges for livestock production: meeting consumer concerns about meat safety and animal welfare. J Agric Environ Ethics $\mathbf{1 2}$, 141-151.

38. Beardsworth A, Bryman A, Keil T et al. (2002) Women, men and food: the significance of gender for nutritional attitudes and choices. Br Food J 104, 470-491.

39. Lockie S, Lyons K, Lawrence G et al. (2004) Choosing organics: a path analysis of factors underlying the selection of organic food among Australian consumers. Appetite $\mathbf{4 3}$, 135-146.

40. Grunert KG (2006) Future trends and consumer lifestyes with regard to meat consumption. Meat Sci 74, 149-160.

41. Bernués A, Olaizola A \& Corcoran K (2003) Labelling information demanded by European consumers and relationships with purchasing motives, quality and safety of meat. Meat Sci 65, 1095-1106.
42. de Boer J, Boersema JJ \& Aiking H (2009) Consumers' motivational associations favoring free-range meat or less meat. Ecol Econ 68, 850-860.

43. Office for National Statistics (2014) Regional Profiles: Key Statistics - East Midlands, August 2012. http://www.ons.gov. uk/ons/rel/regional-trends/region-and-country-profiles/keystatistics-and-profiles- - -august-2012/key-statistics- - -eastmidlands--august-2012.html (accessed December 2014).

44. Gracia A \& Albisu LM (1998) The demand for meat and fish in Spain: urban and rural areas. Agric Econ 19, 359-366.

45. Woodward M (1999) Epidemiology: Study Design and Data Analysis. London: Chapman and Hall.

46. Pettinger C, Holdsworth M \& Gerber M (2006) Meal patterns and cooking practices in Southern France and Central England. Public Health Nutr 9, 1020-1026.

47. Department for Environment Food and Rural Affairs (2012) Family Food Datasets. London: Defra.

48. Clonan A (2011) Understanding consumer attitudes to sustainable food. PhD Thesis, Universtity of Nottingham.

49. Sustain (2009) Consumer Guide to Sustainable Food. http:// www.sustainweb.org/pdf/SFG_Consumers_1pp.pdf (accessed January 2009).

50. Oppenheim AN (1992) Questionnaire Design and Attitude Measurement. London: Pinter Publishers Ltd.

51. Oppenheim AN (2005) Questionnaire Design, Interviewing and Attitude Measurement. London: Continuum.

52. Bowling A (2002) Research Methods in Health; Investigating Health and Health Services. Buckingham: Open University Press.

53. Food Standards Agency (2008) The eatwell plate. http:// www.eatwell.gov.uk/healthydiet/eatwellplate/ (accessed June 2008).

54. Day S, Fayers P \& Harvey D (1998) Double data entry: what value, what price? Control Clin Trials 19, 15-24.

55. Department for Environment Food and Rural Affairs (2008) Animal welfare: Consumer interest in animal welfare. http:// www.defra.gov.uk/animalh/ahws/consumer/interest.htm (accessed June 2009).

56. Eastwood P (1995) Farm animal welfare, Europe and the meat manufacturer. Br Food J 97, 4-11.

57. Channel 4 (2008) Big Food Fight. https://www.channel4sales. com/programming/g/great-british-food-fight-season/

58. Jackson T (2004) Motivating Sustainable Consumption: A Review of Evidence on Consumer Behaviour and Behavioural Change. A Report to the Sustainable Development Research Network. Guildford: University of Surrey.

59. Delormier T, Frohlich KL \& Potvin L (2009) Food and eating as social practice - understanding eating patterns as social phenomena and implications for public health. Sociol Health Ill 31, 215-228.

60. Harper GC \& Makatouni A (2002) Consumer perception of organic food production and farm animal welfare. $\mathrm{Br} \mathrm{Food} \mathrm{J}$ 104, 287-299.

61. Lea E \& Worsley A (2008) Australian consumers' foodrelated environmental beliefs and behaviours. Appetite 50, 207-214.

62. Tobler C, Visschers VHM \& Siegrist M (2011) Eating green. Consumers' willingness to adopt ecological food consumption behaviors. Appetite 57, 674-682.

63. Hoek AC, Luning PA, Stafleu A et al. (2004) Food-related lifestyle and health attitudes of Dutch vegetarians, nonvegetarian consumers of meat substitutes, and meat consumers. Appetite 42, 265-272.

64. De Silva J \& Webster J (editors) (2010) The Meat Crisis: Developing More Sustainable Production and Consumption. London: Earthscan.

65. Pettinger C, Holdsworth M \& Gerber M (2004) Psycho-social influences on food choice in Southern France and Central England. Appetite 42, 307-316. 
66. Taylor N (2012) Reversing Meat-Eating Culture to Combat Climate Change. Haslemere: World Preservation Foundation.

67. Lorinez L (1946) Meat management in the United Kingdom, Australia, New Zealand and Argentina. PhD Thesis, University of Ottawa.

68. BBC (2008) On This Day, 4 July 1954: Housewives celebrate end of rationing. http://news.bbc.co.uk/onthisday/hi/ dates/stories/july/4/newsid_3818000/3818563.stm (accessed September 2012).

69. Morven GM \& Joyce W (2004) Producers and consumers of organic meat: a focus on attitudes and motivations. $\mathrm{Br}$ Food J 106, 534-552.
70. Morven GM \& Claire S (2005) Consumer perceptions of meat production: enhancing the competitiveness of British agriculture by understanding communication with the consumer. Brt Food J 107, 572-593.

71. Stewart K \& Cole M (2009) The conceptual separation of food and animals in childhood. Food Cult Soc 12, 457-476.

72. Saba A \& Di Natale R (1999) A study on the mediating role of intention in the impact of habit and attitude on meat consumption. Food Qual Prefer 10, 69-77.

73. Sparks P, Guthrie CA \& Shepherd R (1997) The dimensional structure of the perceived behavioural control construct. J Appl Soc Psychol 27, 418-438. 